\title{
Immunologically reactive albumin-like protein in human testis and seminal plasma*
}

\author{
C. Orlando, R. Casano, G. Forti, T. Barni, G. B. Vannelli , G. C. Balboni \\ and M. Serio
}

Andrology Unit, Department of Clinical Physiopathology, and $†$ Department of Human Anatomy and Histology, University of Florence, Viale Morgagni 85, 50134 Florence, Italy

\begin{abstract}
Summary. An immunologically reactive albumin-like protein (albumin) was localized, by an immunostaining technique, in the testis of infertile men (normal spermatogenesis, obstructive azoospermia) at the level of the Sertoli cells and in some cells of the germinal epithelium (secondary spermatocytes and early spermatids). No positive reaction was detectable in prepubertal testis.

In vasectomized men, mean seminal albumin values were drastically reduced (by about $80 \%$ ) in comparison to fertile controls, indicating a probable testicular origin. Mean seminal albumin values were also decreased in patients affected by azoospermia due to a seminiferous tubular lesion (about 40\%) and in oligozoospermic patients (about $30 \%$ ). In the same seminal samples transferrin, an index of Sertoli cell function, was also measured. Albumin and transferrin results were well correlated in the seminal plasma of each group (with the exception of vasectomized subjects), including a group of men with abnormally high concentrations of seminal transferrin. A weak correlation was found between seminal albumin and sperm count. We suggest that the presence of albumin in the human adult testis and in seminal plasma could be related to its ability to transport androgens.
\end{abstract}

Keywords: albumin; transferrin; human seminal plasma; Sertoli cell proteins

\section{Introduction}

Human semen contains many protein components which are probably important to provide a suitable environment for the survival and function of spermatozoa. Some of these proteins are specifically secreted by male accessory glands (acid phosphatase by the prostate) or by the epididymis ( $\alpha-1,4$-glucosidase) (Casano et al., 1987). Several other proteins are produced by the Sertoli cell and can be divided into testis-specific (inhibin, ABP) and serum-like (e.g. transferrin, somatomedin-C, ceruloplasmin, plasminogen activator) proteins (Mather et al., 1983). Finally, a specific isoenzyme of lactate dehydrogenase ( $\mathrm{LDH}-\mathrm{X})$ is released by germinal cells of the postpubertal testis (Blanco \& Zinkman, 1963). All these proteins have been extensively studied in human semen in an attempt to determine their physiological role and clinical relevance in evaluation of male fertility.

Besides these 'organ-specific' proteins, human seminal plasma is rich in other proteins, most of which have been clearly identified with electrophoretic techniques (Quinlivan, 1968; Edwards et al., 1981): albumin, lactoferrin, IgA, IgG, fibrinogen, prealbumin, trypsin and several other enzymes. For some of them, their origin as well as their role inside the male genital tract remain to be elucidated. 
Tauber et al. (1975) demonstrated that seminal albumin and transferrin are present in higher concentrations in the first parts of the ejaculate. Bardin et al. (1986) have reported that rat Sertoli cells in culture synthesize a protein which is immunologically and structurally related to serum albumin and which has been termed 'testibumin'. 'Testibumin' secretion is increased both by testosterone and FSH. Testicular and epididymal concentrations of this protein increase in rats from birth to puberty.

In this paper we report the results of immunohistochemical localization of an albumin-like protein (albumin) in the testis of pre-pubertal boys and adult men with normal or abnormal spermatogenesis and the results of albumin measurement, by a very sensitive chemiluminescent method, in seminal plasma of patients affected by infertility of different origin and in normal fertile subjects. In the same samples seminal transferrin, an index of Sertoli cell function in vivo (Orlando et al., 1985), was also measured.

The individual spontaneous variation in time of seminal albumin levels is also reported.

\section{Materials and Methods}

\section{Immunostaining of albumin}

Patients. Testicular biopsies of adult men (26-36 years of age) were obtained under epidural anaesthesia from patients $(\mathrm{N}=8)$ being investigated for obstructive azoospermia. Only men with normal spermatogenesis were considered. Testicular biopsies were obtained from 2 prepubertal boys during orchidopexis for undescended testis; in both boys there was macroscopic evidence of disjunction between the testis and epididymis.

A total of 300 sections were studied; 80 of them were used as control sections.

Reagents and procedure. Albumin (A 8763), rabbit antiserum against human albumin (A 8273) and goat antirabbit IgG peroxidase conjugate (A 8275) were obtained from Sigma Chemical Company, St Louis, MO, U.S.A. Diaminobenzidine $\left(3,4,3^{\prime}, 4^{\prime}\right.$-tetraaminodiphenylhydrochloride) was obtained from BDH Chemicals Ltd (Poole, Dorset, U.K.).

Testicular specimens were fixed in Bouin's solution and processed by peroxidase-antiperoxidase immunocytochemistry (Sternberger, 1979). Sections were first incubated with antiserum against human albumin (titre 1:400 in $0.1 \mathrm{~mm}-\mathrm{PBS}, \mathrm{pH} 7.4$ ) and then with the second antibody-peroxidase conjugate (titre 1:1000). Peroxidase activity was revealed by a $0.225 \mathrm{~mm}$ solution of diaminobenzidine in $0.05 \mathrm{~mm}$ - Tris $-\mathrm{HCl}$ buffer containing $0.01 \% \mathrm{H}_{2} \mathrm{O}_{2}$.

Positive results were checked by serial dilution of specific immune serum (from 1:800 to 1:8000), using the second antibody-peroxidase conjugate alone, incubating with non-immune serum and by preabsorption of specific antiserum with an excess of human albumin.

\section{Albumin assay in seminal plasma}

Patients. The subjects investigated in the first part of the study were divided into four groups: (a) vasectomized subjects, at least 1 year after surgery $(\mathrm{N}=7)$; (b) patients affected by azoospermia due to seminiferous tubular damage $(\mathrm{N}=39)$ proven by testicular biopsy; (c) oligozoospermic men $(\mathrm{N}=69)$ with a sperm count of $<20 \times 10^{6} /$ $\mathrm{ml}$ and $<100 \times 10^{6} /$ ejaculate; (d) a group of 9 subjects ( 3 azoospermic, 3 oligozoospermic and 3 normospermic men, without evidence of haemospermia, confirmed by cytological examination of seminal sediments) who had shown abnormally very high levels of seminal transferrin ( $>99 \%$ confidence limit of the respective sub-group range: mean \pm 3 s.d.). Normal fertile subjects $(\mathrm{N}=71)$ were used as controls.

In the second part of the study 5 fertile male volunteers (30-35 years of age) were investigated to examine the spontaneous variation of the substances measured in semen in this study. They provided semen samples at regular intervals ( 29 days minimum - 32 days maximum) after a fixed sexual abstinence period of 3 days, yielding 12 specimens over 1 year. They were free of any disease during the study period and the administration of any drug was avoided. They were not chosen on the basis of the quality of the semen.

Materials and procedures. Semen collection and analysis were performed according to the World Health Organization recommended procedure (Aitken et al., 1987). Routine examination of semen specimens was always performed by the same technician. All semen samples were collected in our laboratory by masturbation, after 3 days of sexual abstinence, and centrifuged after liquefaction at $1000 \mathrm{~g}$ for $15 \mathrm{~min}$ at $+4^{\circ} \mathrm{C}$. The supernatant was removed and stored at $-20^{\circ} \mathrm{C}$ for albumin and transferrin assay (within 1 week).

Seminal transferrin and albumin were measured by immunochemiluminescent methods previously described (Caldini et al., 1986; Orlando et al., 1987). Human albumin and antialbumin antiserum were the same as those used for the immunohistochemical study. ABENH (7-[(N-4-aminobutyl)- $N$-ethylamino]naphthalene-1,2-dicarboxylic acid hydrazide (Miles Co., Naperville, IL, U.S.A.) was used as the tracer. Preparation and purification of the tracer were as described elsewhere (Messeri et al., 1986). 
The intra- and inter-assay coefficients of variation (calculated on 12 different determinations) were respectively $5 \cdot 1 \%$ and $8 \cdot 5 \%$ for seminal albumin and $7 \cdot 8 \%$ and $9 \cdot 3 \%$ for seminal transferrin determinations. In our laboratory the coefficient of variation of sperm count determinations, performed by the same technician, and assessed in 12 different aliquants of the same semen sample, ranges from 15 to $21 \%$.

Statistical analysis. Statistical analysis of the results was performed by Student's $t$ test and regression analysis of linear correlation. Only the results expressed per total volume of ejaculate were statistically analysed because the total amount of the biochemical measures is a more reliable index than their relative seminal concentrations, which are the result of dilution in the fluids originated by seminal vesicles and prostate.

\section{Results}

\section{Immunohistochemical study}

A clear immunoreactivity for albumin was obtained in Sertoli cells of normal seminiferous tubules (Fig. 1) as well as in those showing different degrees of tubular damage. Positive staining was also evident in all seminiferous tubules at the level of secondary spermatocytes and early spermatids. There was no positive staining in any control sections (Fig. 2). No immunological reaction was present in seminiferous tubules of the prepubertal testes (Fig. 3).
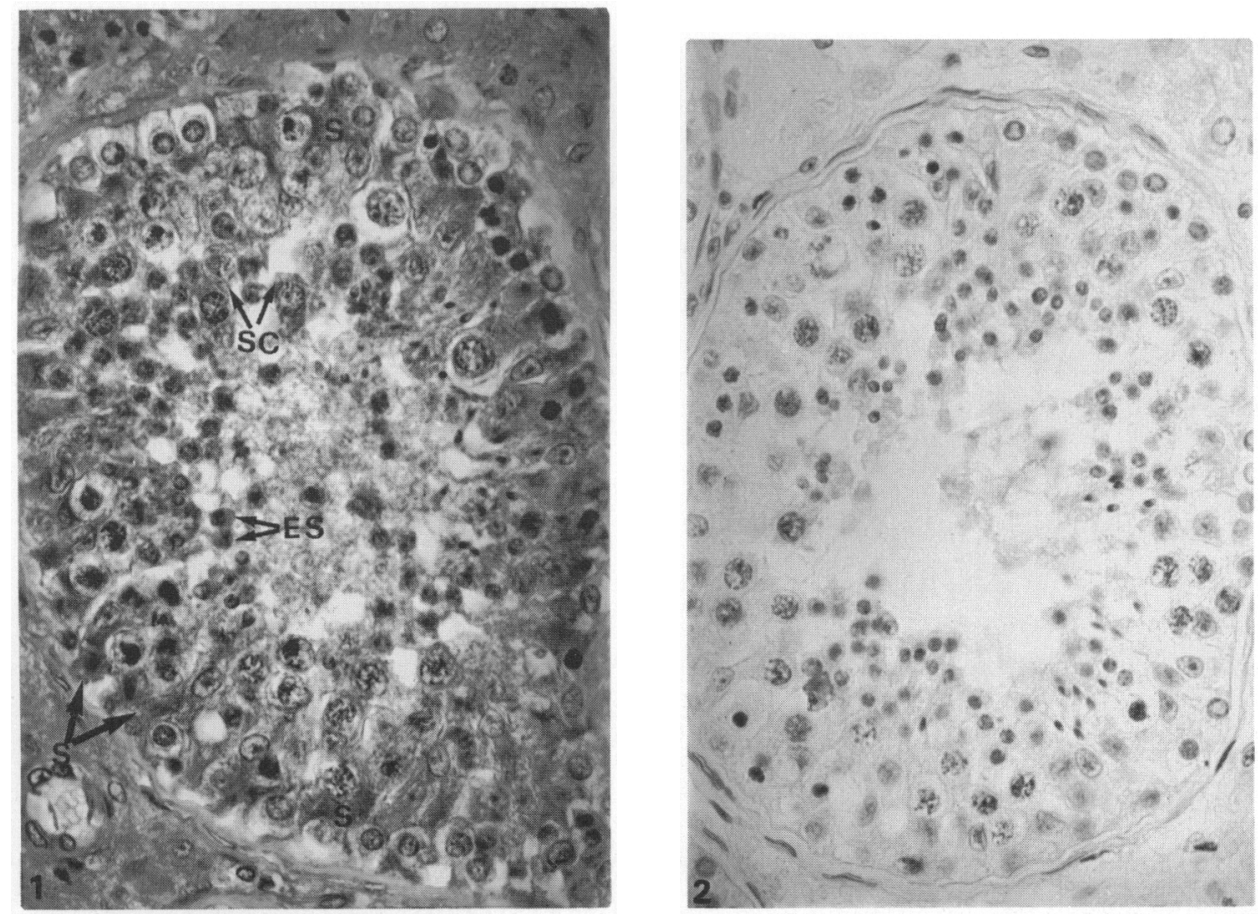

Fig. 1. Section of normal seminiferous tubule treated with antiserum to human albumin (1:400 dilution). Immunoreactive albumin is localized in the cytoplasm of Sertoli cell (S) and in many round cells, interpreted as secondary spermatocytes $(\mathrm{SC})$ and early spermatids $(\mathrm{ES}) . \times 320$.

Fig. 2. Control section incubated with non-immune serum. No positive reaction is detectable. $\times 320$.

\section{Albumin assay}

As shown in Table 1, in vasectomized patients there was a strong and identical decrease (about $80 \%$ of normal controls) in values of albumin and transferrin in semen. Seminal values were also 


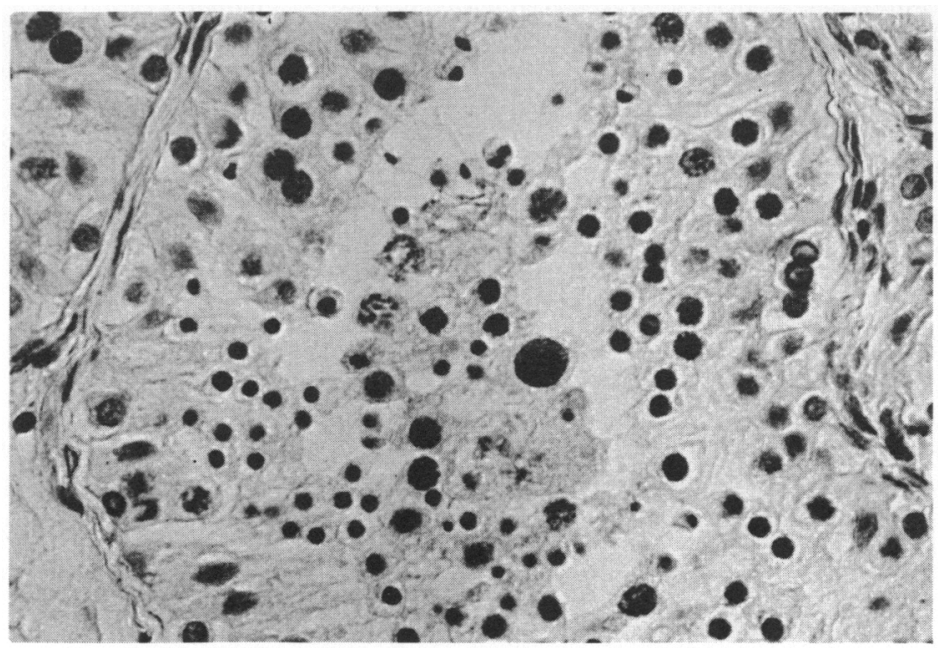

Fig. 3. Section from prepubertal testis. No specific reactivity is detectable (1:400 antiserum dilution). $\times 430$.

Table 1. Seminal values (mean \pm s.e.) of albumin and transferrin in infertile patients and normal controls

\begin{tabular}{|c|c|c|c|c|c|}
\hline & \multicolumn{2}{|c|}{ Albumin } & \multicolumn{3}{|c|}{ Transferrin } \\
\hline & $\mu \mathrm{g} / \mathrm{vol}$ & $\%$ & $\mu \mathrm{g} / \mathrm{vol}$ & $\%$ & $\mathrm{ng} / \mu \mathrm{g}$ albumin \\
\hline Fertile $(N=71)$ & $\begin{array}{r}2700 \cdot 0 \\
\pm 146 \cdot 3\end{array}$ & 100 & $\begin{array}{r}196 \cdot 0 \\
\pm 14.4\end{array}$ & 100 & $\begin{array}{r}75 \cdot 7 \\
\pm 4 \cdot 2\end{array}$ \\
\hline Oligozoospermic $(\mathrm{N}=69)$ & $\begin{array}{l}1924 \cdot 7^{*} \\
\pm 133 \cdot 5\end{array}$ & $71 \cdot 3$ & $\begin{array}{l}89 \cdot 3^{*} \\
\pm 10 \cdot 3\end{array}$ & $45 \cdot 6$ & $\begin{array}{c}45 \cdot 4^{*} \\
\pm 4 \cdot 2\end{array}$ \\
\hline Azoospermic ( $\mathbf{N}=39)$ & $\begin{array}{l}1605 \cdot 4^{*} \\
\pm 142 \cdot 9\end{array}$ & $59 \cdot 5$ & $\begin{array}{l}58 \cdot 4^{*} \\
\pm 9 \cdot 5\end{array}$ & $29 \cdot 8$ & $\begin{array}{l}37 \cdot 6^{*} \\
\pm 4 \cdot 5\end{array}$ \\
\hline Vasectomized $(\mathrm{N}=7)$ & $\begin{array}{l}531.9^{*} \\
\pm 88.1\end{array}$ & $19 \cdot 7$ & $\begin{aligned} & 35 \cdot 6^{*} \\
\pm & 10.9\end{aligned}$ & $18 \cdot 2$ & $\begin{array}{r}78 \cdot 6 \\
\pm 32 \cdot 7\end{array}$ \\
\hline $\begin{array}{l}\text { Abnormally high } \\
\text { transferrin }(N=9)\end{array}$ & $\begin{array}{l}10244 \cdot 0^{*} \\
\pm 1318 \cdot 0\end{array}$ & $379 \cdot 4$ & $\begin{array}{l}690 \cdot 4^{*} \\
\pm 97 \cdot 3\end{array}$ & $352 \cdot 1$ & $\begin{array}{r}69.8 \\
\pm 10.0\end{array}$ \\
\hline
\end{tabular}

*Significantly different from normal controls $(P<0.001)$.

significantly decreased in oligozoospermic men and in patients affected by azoospermia due to seminiferous tubular damage, although the decrease of transferrin values was more evident. In men with abnormally very high concentrations of seminal transferrin there was an identical increase in albumin seminal values (about $3 \cdot 5$-fold). When expressed as micrograms of albumin, seminal transferrin values were still reduced in oligozoospermic and azoospermic patients, while in vasectomized men and in subjects with abnormally high concentrations of seminal transferrin the values were similar to those of normal controls.

A significant correlation was found between seminal albumin and transferrin in each group ( $r=0.6112, P<0.001$ for fertile donors, $r=0.5683, P<0.001$ for oligozoospermic men; $r=$ $0.5312, P<0.001$ for azoospermic men; and $r=0.7064, P<0.005$ for subjects with abnormally high levels of seminal transferrin) with the exception of vasectomized subjects $(r=-0.0545$, not significant). When all subjects were considered, a very high correlation was found ( $r=0.8371$, $P<0.001)$. A weak correlation $(r=0.4244, P<0.001)$ was found between albumin and total 
sperm number; such a correlation was not dissimilar that found between transferrin and sperm count $(r=0.4814, P<0.001)$.

In the study performed on 5 male volunteers to determine the intra-individual variability of seminal albumin and transferrin values, the mean variability (\% coefficient of variation) of seminal albumin (mean: $26.92 \%$; range: $11.47-36.75 \%$ ) was not different from that of transferrin (mean: $27 \cdot 52 \%$; range: $13 \cdot 70-38 \cdot 31 \%$ ) and evidently lower than that of sperm count (mean: $44 \cdot 31 \%$; range: $32 \cdot 28-55 \cdot 56 \%)$. In this study albumin correlated well with transferrin values $(r=0 \cdot 5254$, $P<0.001)$; the correlation with sperm count was very poor even if statistically significant $(r=$ $0 \cdot 3748, P<0.01)$.

\section{Discussion}

Our findings suggest the presence of an immunologically reactive albumin-like protein in Sertoli cells, in secondary spermatocytes and early spermatids of men with normal spermatogenesis. These results seem to be in agreement with the reported hormonally dependent secretion of a protein structurally and immunologically related to serum albumin (called 'testibumin') (Bardin et al., 1986). Immunohistochemical localization revealed that this protein in rats is mainly localized in Sertoli cells and in epididymal epithelium. In addition, the absence of a positive reaction in the human prepubertal testis is in agreement with similar results found in prepubertal rats (Bardin et al., 1986).

The results of the immunohistochemical localization of albumin in the human testis are similar to those obtained by us (Vannelli et al., 1986) for transferrin, a specific iron-carrier protein and an index of Sertoli cell function. According to those results, obtained using a specific monoclonal antibody to transferrin receptors (Vannelli et al., 1986), we suggest that the positive reaction for albumin at the level of secondary spermatocytes and early spermatids could be explained by the presence of a complex albumin-albumin receptor in these cells. The presence of a specific and saturable receptor for albumin has been demonstrated (Brandes et al., 1982; Ockner et al., 1983) in several types of cells (hepatocytes, adipocytes, erythrocytes). This receptor could act by promoting the uptake into target cells of substances bound to albumin (Szego, 1975; Siiteri et al., 1982; Ockner et al., 1983). We therefore suggest that, in addition to androgen binding protein, at the level of seminiferous tubules albumin could also act as a carrier for androgens. Cumming \& Wall (1985) and Manni et al. (1985) have suggested that albumin-bound testosterone as well as free testosterone can readily enter cells because of the short time of dissociation of a testosterone albumin complex (Baird et al., 1969; Pardridge, 1981). Such an hypothesis was also advanced to explain the presence of histoimmunochemically reactive albumin at the level of granulosa cells (Spanel-Borowski, 1987).

The results we obtained for immunochemically reactive albumin in the semen of vasectomized men suggest that the testis is the principal source of seminal albumin, as previously demonstrated for transferrin (Orlando et al., 1985; Caldini et al., 1986). The decrease in seminal values of albumin in oligozoospermic and azoospermic patients was less marked than that found for transferrin, suggesting that the secretion of albumin is a process that is less sensitive to Sertoli cell impairment.

In subjects with abnormally high values of seminal transferrin without evident haemospermia, we found a parallel and marked increase of albumin-like protein concentrations. Such a phenomenon could be explained by an increased permeability of the male genital tract to serum proteins. This hypothesis is supported by the finding of a seminal albumin/transferrin ratio similar to that of serum in these subjects. Furthermore, when expressed in terms of micrograms of albumin, seminal transferrin values were still reduced in oligozoospermic and azoospermic patients in comparison to normal controls. Similarities in the patterns of these two proteins are confirmed by the similar correlation with sperm count and by the identical intra-individual variability over time.

In conclusion, our results demonstrate the presence of a protein, immunologically and structurally related to serum albumin, at the level of the seminiferous tubules of human adult testis. The 
physiological role of this protein is not yet known. However, we suggest that this 'testicular albumin' could act as a carrier of androgens in the tubular compartment.

We thank Dr H. R. Schroeder (Miles Co., IL, U.S.A.) for the gift of ABENH and Dr G. Messeri (Central Laboratory, USL 10/D, Florence, Italy) for the preparation of the chemiluminescent tracers. This paper was supported by a grant of the University of Florence.

\section{References}

Aitken, R.J., Comhaire, F.H., Eliasson, R., Jager, S., Jones, W.R., Kremer, J, de Kretser, D.M., Nieschlag, E., Paulsen, C.A., Wang, C. \& Waites, G.M.H. (1987) WHO laboratory manual for the examination of human semen and semen-cervical mucus interaction. Cambridge University Press, Cambridge.

Baird, D.T., Horton, R., Longcope, C. \& Tait, J.F. (1969) Steroid dynamics under steady state conditions. Recent Prog. Horm. Res. 25, 611-664.

Bardin, C.W., Shaha, C., Grima, J. \& Cheng, C.Y. (1986) The use of Testibumin, a new marker for Sertoli cells, to study testicular physiology. Endocrinology 90 (Suppl.), 90, Abstr. 239.

Blanco, A. \& Zinkham, W.H. (1963) Lactate dehydrogenase in human testis. Science, N.Y. 139, 601-602.

Brandes, R.B., Ockner, R.K., Weisiger, R.A. \& Lysenko, N. (1982) Specific and saturable binding of albumin to rat adipocytes: modulation by epinephrine and possible role in free fatty acid transfer. Biochem. Biophys. Res. Commun. 105, 821-827.

Caldini, A.L., Orlando, C., Barni, T., Messeri, G., Pazzagli, M., Baldi, E. \& Serio, M. (1986) Measurement of transferrin in human seminal plasma by a chemiluminescent method. Clin. Chem. 32, $153-156$.

Casano, R., Orlando, C., Caldini, A.L., Barni, T., Natali, A. \& Serio, M. (1987) Simultaneous measurement of seminal L-carnitine, $\alpha$-1,4-glucosidase and glycerylphosphorylcholine in azoospermic and oligozoospermic patients. Fert. Steril. 47, 324328.

Cumming, D.C. \& Wall, S.R. (1985) Non-sex hormone binding globulin-bound testosterone as a marker for hyperandrogenism. J. clin. Endocr. Metab. 61, 873-876.

Edwards, J.J., Tollaksen, S.L. \& Anderson, N.G. (1981) Proteins of human semen. I. Two-dimensional mapping of human seminal fluid. Clin. Chem. 27, $1335-1340$

Manni, A., Pardridge, M., Cefalu, W., Nisula, B.C., Bardin, C.W., Santner, S.J. \& Santen, R.J. (1985) Bioavailability of albumin-bound testosterone. $J$. clin. Endocr. Metab. 61, 705-710.

Mather, J.P., Gunsalus, G.L., Musto, N.A., Cheng, C.Y., Parvinen, M., Wright, W., Perez-Infante, V., Margioris, A., Liota, A., Becker, R., Krieger, D.T. \& Bardin, C.W. (1983) The hormonal and cellular control of Sertoli cell secretion. J. Steroid Biochem. 19, 41-51.

Messeri, G., Schroeder, R., Caldini, A.L. \& Orlando, C. (1986) Synthesis of chemiluminogenic protein conjugates with dimethyladipimidate for sensitive immunoassays. In Methods in Enzymology: Bioluminescence and Chemiluminescence, Vol. 40, pp. 557-568. Eds M. A. de Luca \& W. McElroy. Academic Press, New York.

Ockner, R.K., Weisiger, R.A. \& Gollan, J.L. (1983) Hepatic uptake of albumin-bound substances: albumin receptor concept. Am. J. Physiol. 245, G13-G18.

Orlando, C., Caldini, A.L., Barni, T., Wood, W.G., Strausburger, C.J., Natali, A., Maver, A., Forti, G. \& Serio, M. (1985) Ceruloplasmin and transferrin in human seminal plasma: are they an index of seminiferous tubular function? Fert. Steril. 43, 290-294.

Orlando, C., Caldini, A.L., Barni, T. \& Casano, R. (1987) A sensitive method for albumin assay in human seminal plasma. In Bioluminescence and Chemiluminescence, pp. 313-316. Eds J. Scholmerich, R. Andreesen, A. Kapp, M. Ernst \& W. G. Wood. John Wiley \& Sons, New York.

Pardridge, W.M. (1981) Transport of protein-bound hormones into tissues in vivo. Endocrine Reviews 2, $103-123$.

Quinlivan, W.L. (1968) Analysis of the proteins in human seminal plasma. Archs Biochem. Biophys. 127, 680-687.

Siiteri, P.K., Murai, J.T., Hammond, G.L., Nisker, J.A., Raymoure, W.J. \& Kuhn, R.W. (1982) The serum transport of steroid hormones. Recent Prog. Horm. Res. 38, 457-503.

Spanel-Borowski, K. (1987) Immunocytochemical localization of albumin in ovarian follicles of fertile rats. Cell Tissue Res. 248, 699-702.

Sternberger, L.A. (1979) The unlabeled antibody peroxidase-antiperoxidase (PAP) method. In Immunocytochemistry, pp. 104-115. John Wiley \& Sons, New York.

Szego, M.C. (1975) Lysosomal function in nucleocytoplasmatic communication. In Lysososmes in Biology and Pathology, vol. 4, pp. 385-477. Eds J. T. Dingle \& R. T. Dean. Elsevier, New York.

Tauber, P.F., Zaneveld, L.J.D., Propping, D. \& Schumacher, G.F.B. (1975) Components of human split ejaculates. I. Spermatozoa, fructose, immunoglobulins, albumin, lactoferrin, transferrin and other plasma proteins. J. Reprod. Fert. 43, 249-267.

Vannelli, B.G., Orlando, C., Barni, T., Natali, A., Serio, M. \& Balboni G.C. (1986) Immunostaining of transferrin and transferrin receptor in human seminiferous tubules. Fert. Steril. 45, 536-541.

Received 20 October 1987 